\title{
THE IMPLEMENTATION OF PROBLEM BASED LEARNING MODEL IN DEVELOPING STUDENTS' HIGHER ORDER THINKING IN SOCIAL STUDIES LEARNING (A Descriptive Study on Teacher in SMP Negeri 40 Bandung)
}

\author{
Niswatul Chadziqoh* \\ aniscrenata@gmail.com
}

\author{
Aim Abdulkarim, \\ Erlina Wiyanarti
}

\begin{abstract}
This research is motivated by the results of initial observation on social studies learning activities conducted by one of the teachers at SMP Negeri 40 Bandung indicating that the implementation of Problem Based Learning (PBL) model is able to develop students' higher order thinking in social studies learning. PBL learning model needs to be developed by the teacher during the learning activities so that students have higher order thinking ability to provision them in facing various challenges in the 21 st century era. For that matter, this study aims to describe the implementation of learning PBL model to develop students' higher order thinking ability. The method used in this study is descriptive method with the subject of research is social studies teacher and students of class IX-D SMP Negeri 40 Bandung, consisting of 30 students. Data collection techniques used to obtain the data on the implementation of PBL model to develop students' higher order thinking ability is observation. The results showed that the implementation of the PBL model can develop students' higher order thinking skills. This is supported by observational data on students' higher order thinking activities developed through the PBL model at the first and second meetings that showed improvement in each of the higher order thinking level areas i.e. analysis, evaluation, and creation.
\end{abstract}

Keywords: Problem Based Learning (PBL) Model, Higher Order Thinking

\section{INTRODUCE}

Education is a systematic and planned effort to develop the potential of learners in order to have knowledge, attitude, and skills needed in community life. Law No. 20 of 2003 on the national education system explains that the aims of education is to develop the potential of learners to become human beings who believe and be cautious to God Almighty, have a noble character, healthy, knowledgeable, capable, creative, independent, and become citizens of a democratic and responsible. This understanding explains that education seeks not only to develop intellectual ability, but also the attitudes and skills students need in facing the 21 st century.

One of the most important things to be done in implementing education in the 21st century is to develop students' thinking skills (ATC21S in Sabar and Maureen, t.t.). Some experts divided thinking skills into two parts: Higher Order Thinking Skills (HOTS) and Lower Order Thinking Skill (LOTS) (Aprianti, 2013, p. 1). Higher order thinking is the ability to think, which consists of the ability to analyze, evaluate, and create, while lower order thinking skill is a low level of thinking that consists of the ability to remember, understand, and apply (Arifin, 2014, pp. 23). The two types of thinking ability, the most important ability for students in facing the 21 st century is higher order thinking ability.

Higher order thinking skill is one of the important skills to be developed by teachers during the learning process because it is related to the achievement of one of the social science learning goals that is to develop students' higher order thinking skill. Hasan (1996, p. 112) states that social science as one of the subjects in school has a role in developing students' higher order thinking skills. In addition, Daldjoeni (1981, pp. 54) also said that the aims social science is to provide a variety of basic understanding, training skills (critical thinking, analyzing and solving problems, determining and gathering information) and developing the various attitudes necessary for students to become useful societies.

In addition to the achievement of IPS learning objectives, higher order thinking skill needs to be developed by teachers in the implementation of learning activities due to several reasons, first, nowadays the students enter the information era where students are surrounded by an infinite number of information. Besides that, the information around the students is not necessarily the truth so that in this case the students need to be equipped with skills in processing and applying information obtained so that students become smart citizens and able to participate in the life of democratic society (Sapriya, 2012, p. 51). Thus, through this higher order thinking ability, students are able to process and apply the various information they obtain. Newman and Wehlage (in Widodo and Kadarwati, 2013) also states that HOTS requires to manipulate information and ideas that transform their meaning and implications, such as when students combine facts and ideas in order to synthesize, generalize, explain, hypothize, or arrive at some conclusion or interpretation. Second, in daily life, students faced so many complex problems and they need to solve it quickly. To solve these problems, students need a higher order thinking skill (Puspitasari, 2016). Thirdly, in the 21st century era, competition in the world of work is getting tighter. In order for students to have high competitiveness, students need to be equipped with higher order thinking skills. This is based on the fact that when entering the workforce students lack of higher order thinking skill, the ability to diagnose and solve problems, the ability to apply their skills to unfamiliar new issues, and the ability to work effectively in groups (Aprianti, 2013, 3).

To achieve social studies learning objectives that can develop higher order thinking skills, the teacher must have the 
skills to manage the learning activities so that the objectives that have been formulated can be achieved. However, in this era, the teachers' skills to carry out learning activities that can develop higher order thinking skills have been increasing. Through various activities and training provided, the teacher has skill in using various learning model which suitable applied to carry out activity of learning that able to facilitate student to think so that student can develop higher order thinking. This is happened in the learning activities undertaken by one of social sudies teachers in SMP Negeri 40 Bandung.

Based on the observation, the teachers have skills in using learning models that can facilitate students to develop higher order thinking skill through the use of Problem Based Learning (PBL) mode in the implementation of learning activities. In the implementation of PBL model, the teachers use a real-world problems that serve as learning materials for students so that students are more interested and able to understand the problems presented by connecting information from the knowledge that he had gained previously with new knowledge that he get. Komalasari (2014, pp. 58-59) states that the PBL model is a learning model that uses real-world problems as a context for students to learn about critical thinking and problem-solving skills, as well as to acquire knowledge and concepts that are the essence of the subject.

In addition, teachers carry out active and collaborative PBL learning activities so that students have more opportunities to be able to exchange ideas and criticize various opinions submitted by friends in order to solve the problems presented. Tan (in Amir, 2010) states that PBL has a characteristic of learning that is collaborative, communicative, and cooperative. Learners work in groups, interact, work with each other (peer teaching) and make presentations. Banks in Supardan (2015) states that through discussion and debate students learn to assess the merits of competing and cooperative arguments in their groups, and to make informed decisions, including consideration of values in recommendations of useful policy alternatives. Then, in learning activities, the teacher using various data and facts obtained from various sources used by students to help solve the problems faced. Tan (in Amir, 2010) states that the implementation of PBL learning uses a variety of knowledge sources, not from a single source. The search, evaluation and use of this knowledge becomes an important key. Based on some of these things, the researcher is interested to conduct a research with the title "THE IMPLEMENTATION OF PROBLEM BASED LEARNING MODEL IN DEVELOPING STUDENTS' HIGHER ORDER THINKING IN SOCIAL STUDIES LEARNING". The formulation of the problem proposed in this study is whether the students' higher order thinking can be developed through PBL model?

\section{METHOD}

The approach used in this research is a qualitative approach with descriptive research design that is used to describe the implementation of PBL model in developing students' higher order thinking skills in social science learning. In the early stages of data collection activities, the researcher conducted interview with social science teacher related to lesson plan that would be used by the teacher. In addition, the researcher conducted a documentation study on the lesson plan made by teachers as well as various questions given by teachers to see the elements of teacher's lesson plan in developing students' higher order thinking in social science learning.

Then, the researcher observed the implementation of PBL model conducted by the teacher to see the stages of what teachers do in implementing PBL model, what principles that teachers develop in the implementation of PBL model to develop higher order thinking skill in learning social studies, and the constraints faced by teachers. Besides that, the researcher also observed the students' higher order thinking ability during the learning process with the PBL model to see the development students' higher order thinking ability in learning social studies.

The participants of the research is a social science teacher and the students of class IX-D consisting of 30 people. Social studies teacher who was selected as participant in this study was selected based on the criteria that in the implementation of learning activities teachers often use PBL model and the use of the model that teachers do have an influence on the development of students' higher order thinking skill. While the class that used as the participants in this study was chosen based on the criteria that the students have a good level of thinking skill because they were accustomed by the use of PBL model conducted by the teacher.

The instruments used in this study included in the form of observation guidelines. Observation guidelines are used to look at the stages of implementing the PBL model by the teacher, the principles of learning that teachers develop in developing higher order thinking skill as well as the development of students' higher order thinking skill who are often involved in the PBL learning model. The data analysis techniques used in this study using Miles and Huberman model consisting of data reduction, presentation of data, and conclusions.

\section{RESULT AND DISCUSSION}

The results of this study described the ability of students' higher order thinking developed by teacher through the implementation of PBL model. To find out whether students' higher order thinking ability can be developed through the PBL model or not the researcher conducted the observation twice. The results of the observations indicated that students' higher order thinking ability improved. Here is the breakdown of the observations on students' higher order thinking skill developed through PBL.

In the first meeting the overall results showed that students' higher order thinking skill developed through the PBL model was sufficient, with a percentage of $43.52 \%$. with the largest percentage is in the indicators able to identify the problem that is equal to $53.33 \%$, while the smallest percentage is in the indicator able to make the hypothesis that is equal to $35.56 \%$. The details of the percentage of each indicator are as follows.

The first indicator of higher order thinking ability is able to analyze relevant or irrelevant and important or unimportant (MMI) information. The result of observation showed that students' higher order thinking ability in this indicator was included in the sufficient category that was $51,11 \%$. The students' higher order thinking ability in this indicator was seen when teachers addressed some questions related to develop and 
developing countries. The teacher provides a table on the profile of developed and developing countries. Then students were asked to observe and answer the differences that existed based on the results of the table. From these activities, it can be seen that the students were quite capable of sorting out relevant or irrelevant information, important and unimportant.

The second indicator of higher order thinking ability was able to identify the problem (MMM). The result of observation showed that students' higher order thinking ability in this indicator is included in sufficient category that is equal to $53,33 \%$. High-level thinking skills in this indicator were seen when students engage in discussion activities. Once teachers provided relevant information on matters related to develop and developing countries students were asked to identify problems that occur in developing countries. From this discussion activity it can be seen that students were quite active and capable in determining a problem related to developing country.

The third indicator of students' higher order thinking was able to provide an assessment (MMN). The result of observation showed that students' higher order thinking ability in this indicator was included in the sufficient category which is $41,11 \%$. The higher order thinking skill of students in this category were seen when they were involved in the discussion and expressed their opinions, they were quite capable of judging that the opinions expressed by the group's friends were appropriate or not. However, it is also seen that some students have not provided an assessment that is accompanied by a clear and strong reason why they think so that in this case the ability of the students in giving assessment was quite adequate.

The fourth indicator of student's higher thinking ability was able to accept or reject a statement (MMP). The result of observation showed that students' higher order thinking ability in this indicator was included in the sufficient category that is equal to $42,22 \%$. The ability of students in this category is seen when the teacher gave students questions related to decision making. Through these questions, it can be seen that some students were able to take decisions so that it can be said that students' higher order thinking ability in this category was still categorized as enough category.

The fifth indicator of the students' higher order thinking ability was hypothesis (MMH). The result of observation showed that students' higher order thinking ability in this indicator wasincluded in the category of less, that was equal to $35,56 \%$. From the results of observations made on learning activities and student discussions, students' higher order thinking ability in this category is still cannot be seen. This was because the time given to the students to do the discussion in making this hypothesis was quite short so that the students' ability in making the hypothesis included into the category less.

The sixth indicator of students' higher order thinking ability was to design an effort to solve the problem (MPM). The result of observation showed that students' higher order thinking ability in this indicator was included in the lesser category, that was $37,78 \%$. Based on the observation of students' higher order thinking ability in this indicator was low due to lack of time given by students to conduct discussion with their group.

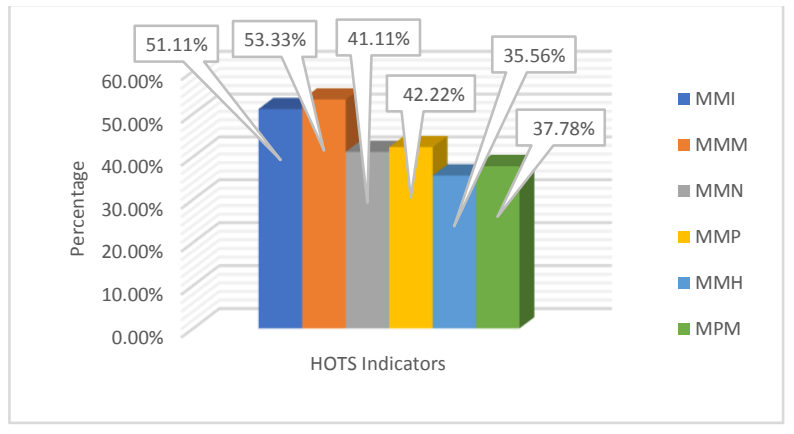

Figure 1

Percentage of Students' HOTS of Meeting 1

In the second meeting, the overall result was that the students' higher order thinking ability still the same as in the previous meeting which was in the sufficient category of $55.92 \%$. However, in the second meeting the results showed an increase of $12.40 \%$ from the previous meeting only amounted to $43.52 \%$. The highest percentage of the indicator of students' higher order thinking ability was in the indicator identify the problem, that is equal to $61.11 \%$, while the lowest percentage was in the indicator accepted or rejected a statement, that was equal to $48.89 \%$. The details of the percentage of each indicator are as follows.

The first indicator of higher order thinking ability was able to sort out relevant or irrelevant, important or unimportant (MMI) information. The result of the observation showed that the students' higher order thinking ability in this indicator was included in the category of enough that was the percentage of $56.67 \%$ and the increase from the previous was only $51.11 \%$ The increase in this indicator was caused by the factor of passive students becomes much more active from the previous meeting so that its ability in sorting information can be more visible.

The second indicator of student's higher order thinking ability was able to identify problem (MMM). The result of observation showed that students' higher order thinking ability in this indicator was included in good category that was $61,11 \%$ and increase from previously only $53,33 \%$. The increase in the ability of students in identifying problems because students already have knowledge and understanding of material that has been previously obtained so that when students were faced in a data, information, and conditions that slightly deviate students could identify that there has been a problem that occurs based on data and information presented.

The third indicator of students' higher order thinking ability was able to provide an assessment (MMN). The result of observation showed that students' higher order thinking ability in this indicator was included in the sufficient category that was equal to $52,22 \%$ and increased from $41,11 \%$ before. The increase in the ability of students in providing assessments can be identified through the way students perceive a solution that was considered most effective for the upside overcome the problems presented. From the results of student discussions on the answers, it can be seen that students were able to provide an assessment of a thing. Students were able to provide assessment according to the criteria but not yet accompanied by reason that was strong enough so that it made the percentage of students' 
ability in providing increased assessment but not included into a good category.

The fourth indicator of students' higher order thinking ability was being able to accept or reject a statement (MMP). The result of observation showed that students' higher order thinking ability in this indicator was included in the enough category, that was equal to $48.89 \%$ and has increased from the previous only by $42.22 \%$. The increase in this indicator was due to the fact that in the implementation of the problem-based learning model the teacher provides opportunities for students to learn actively and collaboratively. They could hold discussions with their friends' group, which in turn would happen an exchange of opinions with each other so that when one of his friends put forward his opinion and he disagreed, then he could said disagreement was so indirectly the ability of students to receive or rejecting a statement would be more honed.

The fifth indicator of students' higher order thinking ability was able to make a hypothesis (MMH). The result of observation shows that the students' higher order thinking ability in this indicator was included in the sufficient category, that was 58,89\% and increase from previous meeting which only $35,56 \%$. The increase in this second meeting by the time given by the teacher to the discussion was sufficient so that the student were better able to make a hypothesis in accordance with the problems presented.

The sixth indicator of the students' higher order thinking ability was able to design problem solving (MPM). The result of observation showed that the students' higher order thinking ability in this indicator was included in the category of $57,58 \%$ and increase from previous meeting which only $37,78 \%$. In this meeting, most of the students who were actively involved in the discussion process were able to design a solution that suited the problems presented, but the students had not provided an argument or reason why they designed the solution so that students' ability in this indicator was still sufficient.

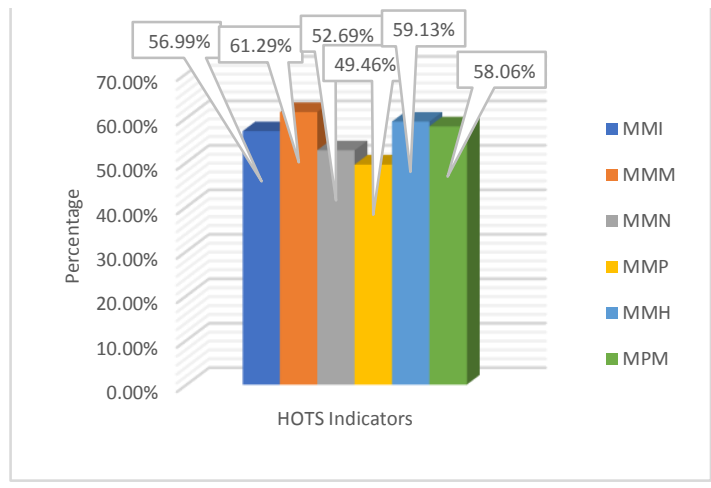

Figure 2

Student HOTS Percentage of Meeting II

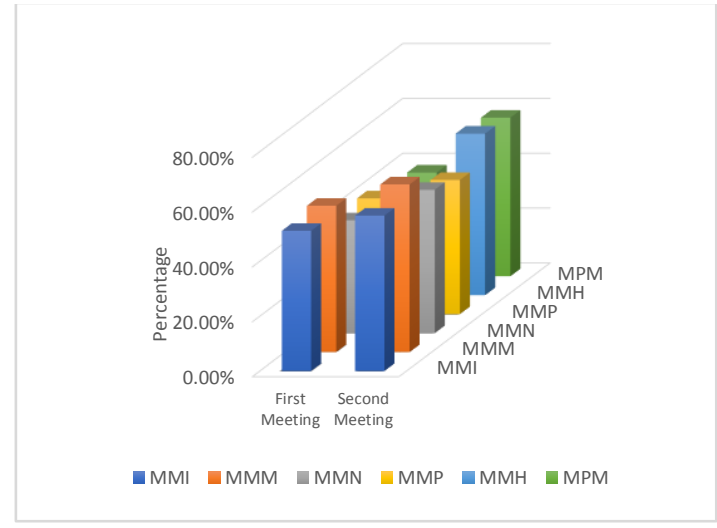

Figure 3

\section{Students' HOTS Differences at Meeting I and II}

\section{DISCUSSION}

Based on observational data made during the implementation of PBL model, it was found that students' higher order thinking ability could be developed through PBL model. This was certainly in accordance with existing theory as proposed by Ibrahim and Nur (in Rusman, 2014) who states that problem-based learning is one of the learning models used to stimulate higher order thinking. Wang, et al. (in Karmana, 2013) also states that PBL plays a role in developing thinking skills and problem solving. Successful implementation of PBL model in developing students' higher order thinking ability was due to several things, first in implementing PBL model, the teacher used real problems for students. Through this problem the teacher asked the students to find solutions that match with the existing problems. To solve the problem, the students will acquire higher order thinking skills. This is in accordance with the theory proposed by Saregar (2016), Dewey (in Hasan, 1996), and Baharuddin (2009) who state that one way of improving students' higher order thinking is by confronting learners in a problem they have encountered. The problem requires a solution (problem solving). To solve the problem, one must find a relationship and determine the related problem with each other, analyze the cause and then find the laws and determine the problem solving faced. Puspitasari (2016) also stated that the PBL learning model provides an opportunity for students to acquire skills in problem solving so that higher order thinking skills can be developed.

Secondly, in implementing PBL models, teacher provided opportunities for students to be active and use the experience they have for solving the problems faced so that students can develop their higher order thinking skills. This is in line with the theory expressed by Mayer (in Anderson and Krathwohl, 2015) stating that PBL is a learning model that provides an opportunity for students to be active in learning process. In this model, the students actively cognate the process, which is to observe relevant information that comes, organize information in the brain into a coherent picture and combine that information with the knowledge stored in the brain.

Widodo and Kadarwati (2013), Anderson and Krathwohl (2015, p. 97) also states that the problem-solving model with 
higher order thinking will bring the student to the experience of using knowledge and skills to the maximum to be applied in terms of non-routine problem solving, discovery of patterns of solving, result placement and good communication skills, so that meaningfulness learning will be more pronounced. This meaningful lesson will ultimately present the knowledge and cognitive processes that students need to solve the problem.

Thirdly, in the implementation of learning, the teacher used several sources that students used to design a problem-solving effort. By using a variety of resources that require students to pay attention and analyze the information in accordance with the problems presented, find the relationship between one information with other information until he was able to design efforts to solve the problem. This is similar to Tan (in Amir, 2010) who states that PBL learning utilizes a variety of knowledge resources, not from a single source. The search, evaluation, and use of this knowledge become an important key.

\section{CONCLUSION}

Based on the results of the research, it can be concluded that the implementation of the PBL model can develop students' higher order thinking skill. This is supported by observational data which showed that the percentage of each indicator of students' higher order thinking ability has increased. The reason was that during the implementation of the PBL model, the teacher facilitated the students to develop their higher order thinking skill. The teacher exposed the students to a problem, and in an effort to solve the problem students did various activities that involved high-level cognitive ability so that students could develop higher order thinking with a better level.

\section{ACKNOWLEDGEMENT}

In this occasion, the researcher thank to Dr. Dadang Sundawa, M.Pd. as the head of Social Studies Education Program, Prof. Dr. Aim Abdulkarim, M.Pd. as first supervisor who has given a lot of guidance, motivation and guidance to the author in completing this skripsi, Mrs. Erlina Wiyanarti, M.Pd. as second supervisor who has provided a lot of guidance, motivation and guidance to the author in completing this skripsi, Mrs. Dra. Herlina as a participant in this research who has provided support and facilitated the researcher in conducting research, and students of IX-D SMP Negeri 40 Bandung.

\section{REFERENCES}

Amir, M.T. (2010). Innovation of Education through Problem Based Learning: How Educators Empower Learners in the Era of Knowledge. Jakarta: Kencana.

Anderson, L.W. \& Krathwohl, D.R. (2015). A Taxonomy for Learning, Teaching, and Assesing: A revision of Bloom's Taxonomy of Education. Yogyakarta: Pustaka Pelajar.

Aprianti, V. (2013). Influence Implementation of Cooperative Learning Type Think Pair Share (TPS) on Critical Thinking Skills of Students in Economic Learning.
(Undergraduate Thesis). Indonesia University of Education, Bandung.

Arifin, Z. (2014). The Evaluation of Learning. Bandung: PT Remaja Rosdakarya.

Baharuddin. (2009). Educational Psychology: Theoretical Reflection on Phenomena. Yogyakarta: Ar-Ruzz Media.

Daldjoeni, N. (1981). Social Science Basics: An Introduction Book for Students and Teachers. Bandung: Penerbit Alumni.

Hasan, S.H. (1996). Social Science Education. Jakarta: Departemen Pendidikan dan Kebudayaan.

Karmana, W.I. (2013). Empowering high order thinking students in Biology learning. Journal of Prism Science, 1 (1), page. 55-65. [Online]. Accesed from http://ejournal.pkpsmikip mataram.org/index.php/prisma/article/view/31/13.

Komalasari, K. (2014). Contextual Learning: Concepts and Aplication. Bandung: Refika Aditama.

Puspitasari, S.D. (2016). The use of problem solving method to improve higerb order thinking skills in social studies class IV Karanggondang Elementary School. Journal of Primary School Teacher Education, (7). [Online]. Accesed from top/doc/314485/penggunaan-metode-problem-solvinguntuk-meningkatkan-berp.

Rusman. (2014). Model-Model Pembelajaran: Mengembangkan Profesionalisme Guru. Jakarta: PT Raja Grafindo Persada.

Sabar \& Maureen. (t.t.). The Development Module to Increase Higher Order Thinking Skill in the Course of Learning Strategy Student of FIP-UNESA Education Technology Study Program. [Online]. Accessed fromhttps://drive.google .com/file/d/0Bk3cSUkM3Iydk1mNV9CNtDVEE/viewhttps:// drive.google.com/file/d/0Bk3cSUkM3Iydk1 mNV9NtDVEE/v iew.

Sapriya. (2012). Social Studies Education. Bandung: PT Remaja Rosdakarya.

Saregar, A. (2016). Effectiveness of Learning Model CUPs: Impact on Thinking Ability Students Madrasah Aliyah Mathla'ul Anwar Gisting Lampung. Scientific Journal of Physics Education Al-Biruni, 5(2), page. 235-246. [Online]. Accessed from https://www.researchgate.net/publication/310447902_THE_E FFECTIVENESS_OF_MODEL_LEARNING_CUPs_IMPAC T ON_THE_HIGHER_ORDER_THINKING_SKILL_STUD ENTS_AT_MADRASAH_ALIYAH_MATHLA'UL_ANWA R_GISTING_LAMPUNG.

Supardan, D. (2015). Social Science Learning: Philosophy and Curriculum Perspective. Jakarta: Bumi Aksara.

Widodo, T. \& Kadarwati, S. (2013). Higher order thinking: Problem-Based Troubleshooting to Improve Formed Learning Outcomes Student Character, (1). Education Firmament Journals [Online]. Accessed from https://www.google.co.id/url?sa=t\&rct=j\&q=\&esrc=s\&source $=$ web $\& c d=4 \& c a d=$ rja $\&$ uact $=8 \& v e d=0$ ahUKEwjAy_PD05vR AhXLPI8KHRFeCYEQFgg4MAM\&url=http\%3A\%2F\%2Fjo urnal.uny.ac.id\%2Findex.php $\% 2$ Fcp $\% 2$ Farticle $\% 2$ Fdownload \%2F1269\%2Fpdf\&usg=AFQjCNEOuh2TQ_RT9zIcWR9Xxr 7ScsROJw\&sig2=fuy0jdJyXHKoviTyPi1TjQ.

https://id.m.wikipedia.org/wiki/Tujuan_pendidikan 